Article

\title{
Synthesis of biaryls using palladium nanoparticles immobilized on peptide nanofibers as catalyst and hydroxybenzotriazole as novel phenylating reagent
}

\author{
Arash Ghorbani-Choghamarani *,Zahra Taherinia \\ Department of Chemistry, Faculty of Science, Ilam University, P.O. Box 69315516, Ilam, Iran
}

\section{A R T I C L E I N F O}

\section{Article history:}

Received 28 August 2016

Accepted 10 October 2016

Published 5 March 2017

\section{Keywords:}

Peptide nanofiber

Hydroxybenzotriazole

Biaryl

PEG

Palladium

\begin{abstract}
A B S T R A C T
Peptide nanofibers decorated with palladium nanoparticles catalyzed direct coupling of aryl halides with hydroxybenzotriazole to afford the corresponding biaryls in good to excellent yields. The coupling reactions proceeded under simple, green, and mild conditions. The peptide nanofibers were used as recyclable supports in the coupling reactions. This approach is the first to use hydroxybenzotriazole as a phenylating agent.
\end{abstract}

(C) 2017, Dalian Institute of Chemical Physics, Chinese Academy of Sciences. Published by Elsevier B.V. All rights reserved.

[12]. Self-assembly is the most popular strategy to fabricate nanofibers. In this procedure, molecules organize themselves into structures through non-covalent forces such as hydrogen bonding and hydrophobic forces. Self-assembly techniques show good potential to realize novel scaffolds for tissue engineering applications. Factors like the concentration of peptide molecules, medium $\mathrm{pH}$, solvent polarity, sonication, ionic strength [13], and interaction with anions such as phosphate affect the self-assembly process.

The Suzuki-Miyaura cross-coupling reaction between organoboron compounds and organic halides or triflates is a powerful general methodology to form carbon-carbon bonds. However, there are some drawbacks that accompany this approach. For example, the tricoordinate nature of these compounds makes them highly moisture sensitive. To minimize atmospheric oxidation and autoxidation, organoboron compounds should be stored under an inert atmosphere, and also their reaction products need to be isolated and purified be-

\footnotetext{
* Corresponding author. Tel/Fax: +98-841-2227022; E-mail: a.ghorbani@mail.ilam.ac.ir, arashghch58@yahoo.com 
cause of the formation of boroxines through simple dehydration of boronic acids [14]. Therefore, it is necessary to find a new procedure to solve these problems. We decided to investigate a novel phenylating agent, hydroxybenzotriazole, and its ability to couple with aryl halides to form biaryls.

Herein, peptide nanofibers are prepared through the self-assembly of a peptide containing arginine as building block (Scheme 1). After formation of the nanofibers, palladium (Pd) NPs are immobilized on their surface. The catalytic ability of this compound in the synthesis of biaryls via the coupling reaction of aryl halides and hydroxybenzotriazole as a novel phenylating agent is then studied.

\section{Experimental}

\subsection{Materials}

Chemicals and solvents used in this work were obtained from Sigma-Aldrich, Fluka, or Merck and used without further purification. Arginine ethyl ester hydrochloride, compounds 1, 2, and 3, peptide nanofibers (PNFs), and Pd nanoparticles supported on peptide nanofibers (PdNP-PNF) were prepared according to our previous report [8].

\subsection{General procedure for the synthesis of biaryls}

A round-bottom flask was charged with an aryl halide (1 mmol), hydroxybenzotriazole (1 mmol), $\mathrm{KOH}(3 \mathrm{mmol})$, PdNP-PNF (200 $\mu \mathrm{L})$, and polyethylene glycol (PEG)-400 (2 mL). The reaction mixture was stirred at $130{ }^{\circ} \mathrm{C}$ under atmospheric conditions. Reaction progress was monitored by thin-layer chromatography (TLC). Upon completion of the reaction, the mixture was cooled to room temperature, filtered, and then extracted with ethyl acetate. The combined organic layers were dried over $\mathrm{Na}_{2} \mathrm{SO}_{4}$, filtered, and then purified by preparative TLC using $n$-hexane/ethyl acetate as the eluent.

4-Methoxy biphenyl. ${ }^{1} \mathrm{H} \mathrm{NMR}\left(400 \mathrm{MHz}, \mathrm{CDCl}_{3}\right): \delta_{\mathrm{H}}=3.89(\mathrm{~s}$, $3 \mathrm{H}), 7.03(\mathrm{dt}, J=8.8,2.4 \mathrm{~Hz}, 2 \mathrm{H}), 7.34(\mathrm{tt}, J=7.6,1.2 \mathrm{~Hz}, 1 \mathrm{H})$, $7.45(\mathrm{t}, J=7.6 \mathrm{~Hz}, 2 \mathrm{H}), 7.58(\mathrm{~m}, 4 \mathrm{H}) \mathrm{ppm}$.

4-Methyl-1,10-biphenyl. ${ }^{1} \mathrm{H}$ NMR (400 $\left.\mathrm{MHz}, \mathrm{CDCl}_{3}\right): \delta=$ 7.66-7.64 (m, 2H), 7.58-7.56 (m, 2H), 7.52-7.47 (m, 2H), 7.41-7.37 (tt, $J=7.2,1.2 \mathrm{~Hz}, 1 \mathrm{H}), 7.33-7.31(\mathrm{~d}, J=8 \mathrm{~Hz}, 2 \mathrm{H})$, 2.47 (s, 3H) ppm; ${ }^{13} \mathrm{C}$ NMR (400 MHz, $\mathrm{CDCl}_{3}$ ): $\delta=141.2,138.4$, 137.1, 129.6, 128.8, 127.1, 127.0, $21.2 \mathrm{ppm}$.

4-Chloro-1,10-biphenyl. ${ }^{1} \mathrm{H}$ NMR (400 $\left.\mathrm{MHz}, \mathrm{CDCl}_{3}\right): \delta=$ 7.60-7.58 (m, 2H), 7.57-7.54 (m, 2H), 7.50-7.43 (m, 4H), $7.42-7.38(\mathrm{tt}, J=6,1.6 \mathrm{~Hz}, 1 \mathrm{H}) \mathrm{ppm} ;{ }^{13} \mathrm{C}$ NMR $\left(400 \mathrm{MHz}, \mathrm{CDCl}_{3}\right)$ : $\delta=140.0,139.7,133.5,129.0,128.9,128.5,127.7,127.1 \mathrm{ppm}$.

4-Nitrobiphenyl. ${ }^{1} \mathrm{H}$ NMR $\left(400 \mathrm{MHz}, \mathrm{CDCl}_{3}\right): \delta=8.33(\mathrm{~d}, J=$ $8.8 \mathrm{~Hz}, 2 \mathrm{H}), 7.77(\mathrm{~d}, J=8.8 \mathrm{~Hz}, 2 \mathrm{H}), 7.67-7.64(2 \mathrm{H}, \mathrm{m})$, 7.56-7.51 (2H, m), 7.50-7.46 (1H, m) ppm.

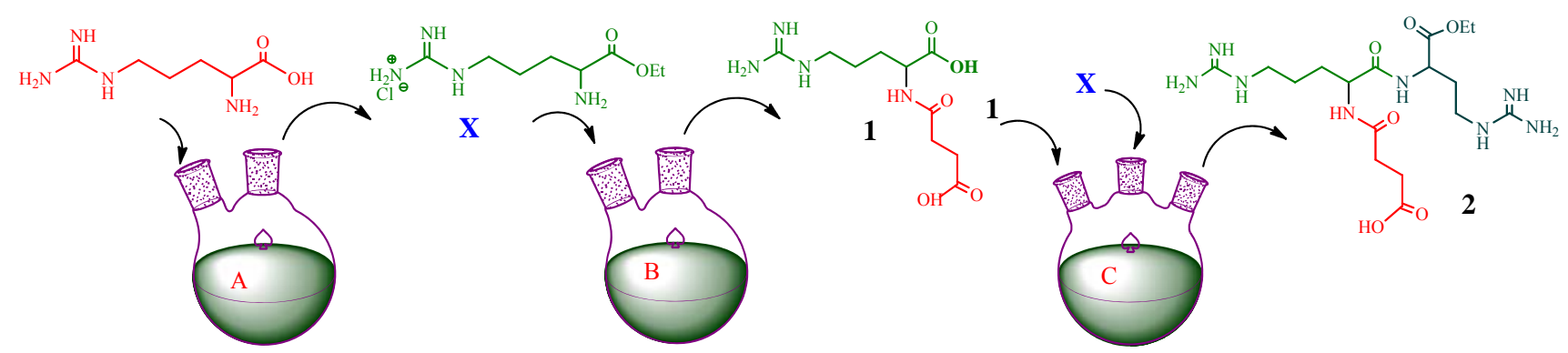

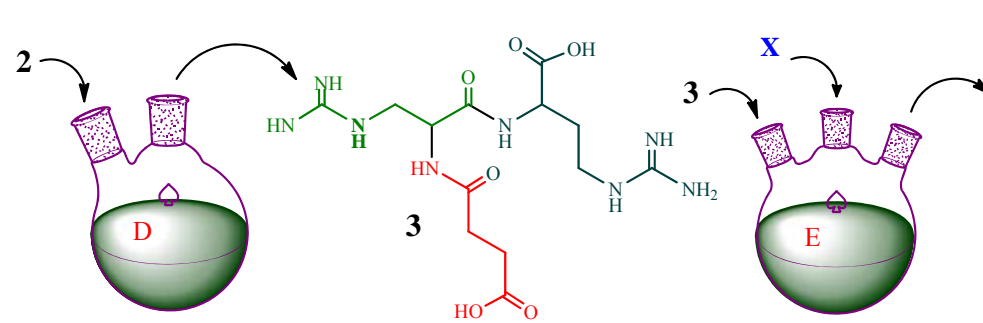

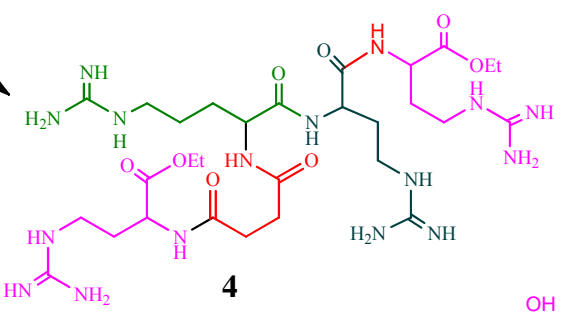

4

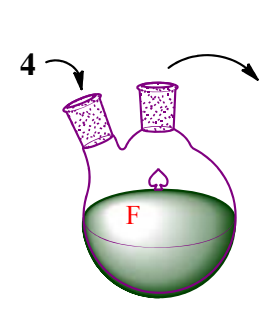<smiles>N=C(N)CCCCCCCCCCCNC(=N)N</smiles>

5

$\mathrm{A}=\mathrm{SOCl}_{2}, \mathrm{EtOH} ; \mathrm{B}=$ Succinic anhydride, $\mathrm{DMF}, N$-methyle morpholine; $\mathrm{C}=\mathrm{HOBt}, \mathrm{DCC}, \mathrm{DMF} ; \mathrm{D}=\mathrm{EtOH}, \mathrm{NaOH} ; \mathrm{E}=\mathrm{HOBt}, \mathrm{DCC}, \mathrm{DMF} ; \mathrm{F}=\mathrm{EtOH}, \mathrm{NaOH}$; $\mathrm{G}=(1)$ phosphate buffer solutions $(\mathrm{pH}=8)$ and succinic anhydride; (2) $\mathrm{Pd}(\mathrm{OAC})_{2}$; (3) $\mathrm{NaBH}_{4}$ 


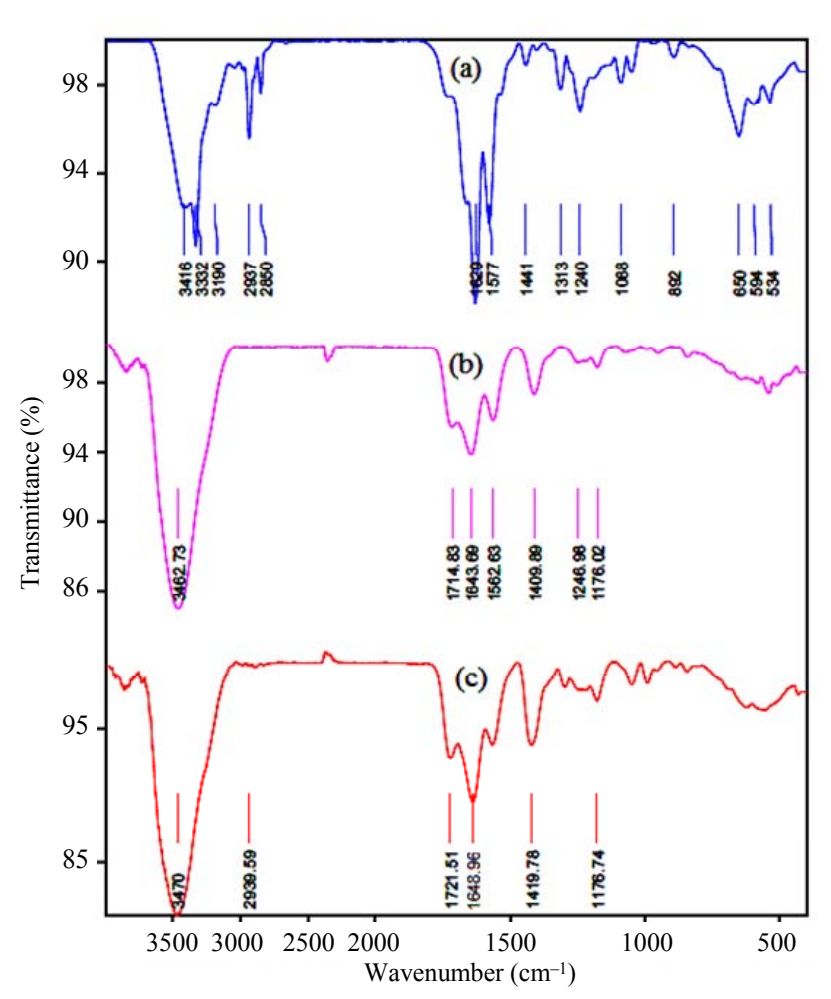

Fig. 1. FT-IR spectra of (a) peptide powder, (b) peptide nanofibers, and (c) PdNP-PNF.

\section{Results and discussion}

\subsection{Characterization of peptide nanofibers}

The self-assembly of the PNFs was investigated using various spectroscopic and microscopic techniques. Fourier transform infrared (FT-IR) spectroscopy was used to study the structure of the nanofiber solution. The peak at $1644 \mathrm{~cm}^{-1} \mathrm{ob}-$ served for the PNF solution (Fig. 1(b)) could be assigned to the bending vibration of $\mathrm{N}-\mathrm{H}$ groups. This peak was observed at $1629 \mathrm{~cm}^{-1}$ for the peptide powder (Fig. 1(a)), which indicates the involvement of $\mathrm{N}-\mathrm{H}$ bonds in hydrogen bonding between phosphate and the peptide in the self-assembled structure of the PNFs. Generally, hydrogen bonding decreases the frequen-

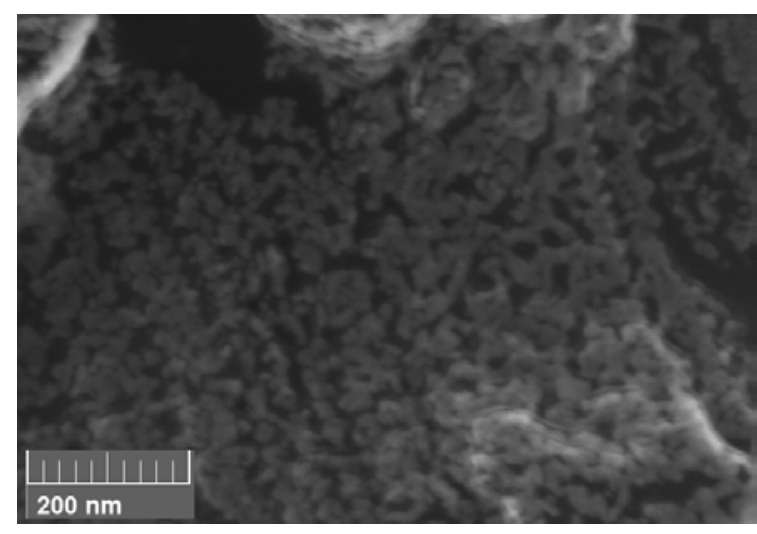

Fig. 2. SEM image of the woven peptide nanofibers.

cy of stretching vibrations and increases the frequency of bending vibrations [15].

The scanning electron microscopy (SEM) image showed the morphology of the woven nanofiber structures (Fig. 2). The structure is similar to that of previously reported nanofibers $[16,17]$.

\subsection{Characterization of PdNP-PNF catalyst}

The structure of PdNP-PNF was investigated by FT-IR spectroscopy and transmission electron microscopy (TEM). The FT-IR spectrum of PdNP-PNF contained the bending vibration of $\mathrm{N}-\mathrm{H}$ groups at $1648 \mathrm{~cm}^{-1}$ (Fig. 1(c)), which is shifted to higher frequency compared with that of the PNFs. The morphology and distribution of the Pd NPs on the nanofibers were examined by TEM. As shown in Fig. 3, the TEM images of PdNP-PNF reveal that the Pd NPs possessed a very uniform size distribution and did not agglomerate. Inductively coupled plasma optical emission spectrometry (ICP-OES) was used to estimate the amount of Pd in PdNP-PNF. Based on the results of ICP-OES, the amount of Pd incorporated into the nanofibers was $250 \mathrm{ppm}$.

\subsection{Catalytic activity}

After preparation and characterization of PdNP-PNF, the
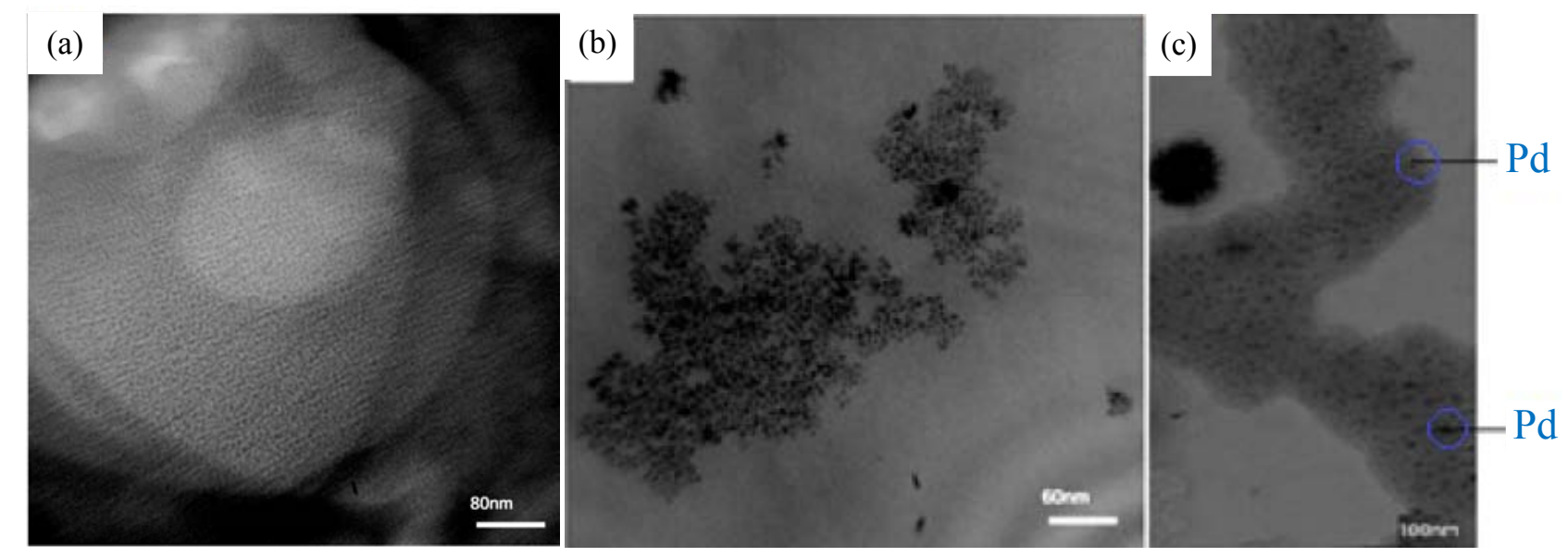

Fig. 3. (a) SEM image and (b, c, d) TEM images of immobilized Pd nanoparticles on the surface of woven nanofibers. 
catalytic activity of this compound in the direct synthesis of biaryls from the reaction of different aryl halides with hydroxybenzotriazole as a novel phenylating reagent was investigated. To optimize reaction conditions, iodobenzene and hydroxybenzotriazole were used as a model reaction system. The effects of bases, such as $\mathrm{K}_{2} \mathrm{CO}_{3}, \mathrm{KOH}$, and $\mathrm{Et}_{3} \mathrm{~N}$, and organic solvents, including $\mathrm{H}_{2} \mathrm{O}$, DMF, DMSO, and PEG, on the outcome of the reaction were determined. The obtained results are summarized in Table 1. We found that using PEG as the solvent and $\mathrm{KOH}$ as the base gave the highest yield of the coupled product at $130^{\circ} \mathrm{C}$.

With the optimized conditions in hand, the reactions of different aryl halides with hydroxybenzotriazole were examined to explore the scope of this procedure. The results are presented in Table 2. To our delight, the reaction proceeded smoothly in the presence of a variety of functional groups including methoxy, methyl, iodo, bromo, chloro, trifluoride, and nitro moieties (Table 2). In general, reactions were very clean and the biaryl derivatives were obtained in high yields under the optimized conditions. Our results reveal that substitution played a major role in governing the reactivity of the substrate. Generally, the electron-donating groups produced the corresponding products in slightly higher yields than electron-withdrawing ones. The methoxy group with a stronger electron-donating ability than methyl achieved a higher yield, whereas in the presence of an electron-withdrawing group $\left(\mathrm{CF}_{3}, \mathrm{NO}_{2}\right)$, a slight decrease in the yield of the biaryl was observed. It is noteworthy that all of the groups in aryl halides commonly used for cross-coupling reactions, such as chloro and bromo, were tolerated and afforded the biaryl products in moderate yields. Also, the reaction yields were sensitive to steric effects of the aryl halides, such as 2-methyl- and 2-methoxy-substituted aryl halides. A sterically hindered ortho-substituted aryl halide proved to be problematic for this catalyst system and gave a much lower yield than the other substrates. Overall, this experimental procedure is very simple and convenient, and has the ability to tolerate a variety of different functional groups such as $\mathrm{CF}_{3}, \mathrm{NO}_{2}$, alkyl, and $\mathrm{OCH}_{3}$ under the optimized reaction conditions.

The proposed mechanism of the described cross-coupling reaction is outlined in Scheme 2. Although the exact reaction

\section{Table 1}

Optimization of the reaction conditions for the synthesis of biphenyl.

\begin{tabular}{lcccc} 
& & & \\
Entry & Solvent & Temp. $\left({ }^{\circ} \mathrm{C}\right)$ & Base & Yield $^{\mathrm{a}}(\%)$ \\
\hline 1 & $\mathrm{DMSO}$ & 130 & $\mathrm{KOH}$ & 30 \\
2 & $\mathrm{DMF}$ & 130 & $\mathrm{KOH}$ & - \\
3 & $\mathrm{H}_{2} \mathrm{O}$ & 130 & $\mathrm{KOH}$ & - \\
4 & $\mathrm{PEG}$ & 130 & $\mathrm{KOH}$ & 90 \\
5 & $\mathrm{PEG}$ & 130 & $\mathrm{~K}_{2} \mathrm{CO}_{3}$ & - \\
6 & $\mathrm{PEG}$ & 130 & $\mathrm{Et}_{3} \mathrm{~N}$ & - \\
7 & $\mathrm{PEG}$ & 100 & $\mathrm{KOH}_{1}^{N}$ & PdNP-PNF(Cat) \\
8 & $\mathrm{PEG}$ & 80 & $\mathrm{KOH}$ & - \\
\hline
\end{tabular}

Reaction conditions: iodobenzene $1 \mathrm{mmol}$, hydroxybenzotriazole 1 mmol, PdNP-PNF $200 \mu \mathrm{L}$, solvent $2 \mathrm{~mL}$. ${ }^{\text {a }}$ Isolated yield. mechanism is not understood completely, we believe that the aryl halide reacts with $\mathrm{Pd}$ to generate intermediate $\mathbf{F}$, which adds to nitroarene to oxidatively produce intermediate $\mathbf{G}$ via $\mathrm{C}-\mathrm{N}$ bond cleavage [18]. Finally, the product is obtained by reductive elimination. To confirm the proposed mechanism and formation of nitrobenzene, gas chromatography-mass spectrometry was used to probe the reaction of 4-iodoanisole with hydroxybenzotriazole. The ultimate spectrum confirmed the presence of nitrobenzene in the reaction mixture (Fig. 4).

To confirm the catalytic cycle in this mechanism, the synthesis of 4-nitrobiphenyl from nitroarene and 4-bromonitrobenzene was studied under the optimal reaction conditions, which gave a yield of 4-nitrobiphenyl of 85\% (Scheme 3).

From an industrial point of view, the reusability and recyclability of catalysts are two of their most important aspects. The reusability of PdNP-PNF in the cross coupling of 4-iodoanisole with hydroxybenzotriazole was investigated. After completion of the reaction, the mixture was cooled to room temperature and ethyl acetate $(20 \mathrm{~mL})$ was added to the

\section{Table 2}

Synthesis of biaryls using PdNP-PNF in PEG.

(1) (C)

Reaction conditions: aryl halide $1 \mathrm{mmol}$, hydroxybenzotriazole $1 \mathrm{mmol}$, PdNP-PNF $200 \mu \mathrm{L}, \mathrm{PEG} 2 \mathrm{~mL}$. a Isolated yield. 


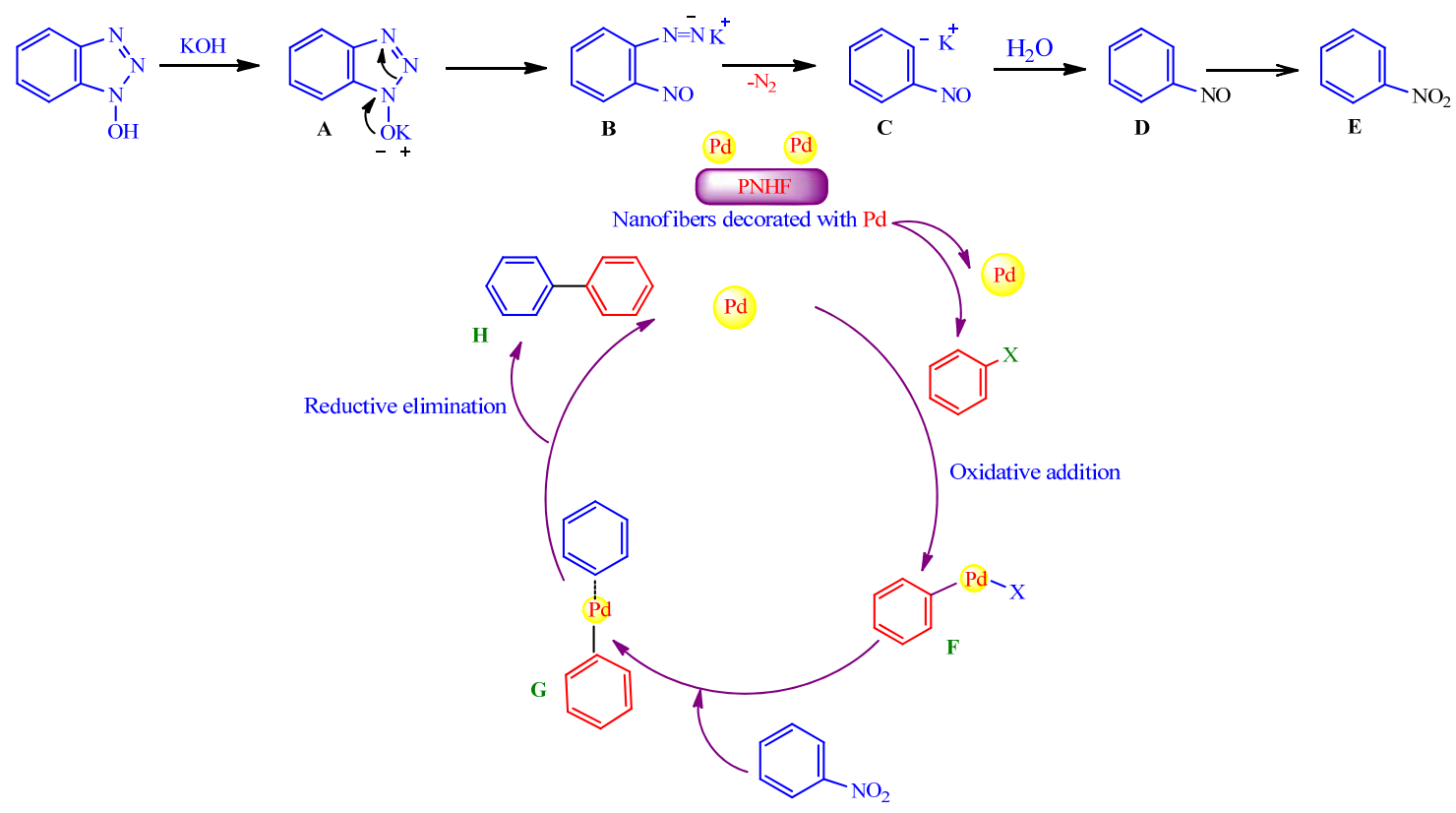

Scheme 2. Proposed mechanism for the synthesis of biaryls catalyzed by peptide nanofibers.

reaction mixture to precipitate PdNP-PNF. The resulting precipitate was washed twice with ethyl acetate $(2 \times 20 \mathrm{~mL})$, dried, and then reused in another run. It was found that PdNP-PNF could be reused at least four times without marked loss of its catalytic activity (Table 3). To measure the exact leaching of $\mathrm{Pd}$ from the catalyst, the amount of Pd in PdNP-PNF after recycling four times was determined using ICP-OES. Based on ICP-OES, the amount of Pd in the catalyst after four runs was $230 \mathrm{ppm}$, meaning that leaching of $\mathrm{Pd}$ during the reaction is negligible.

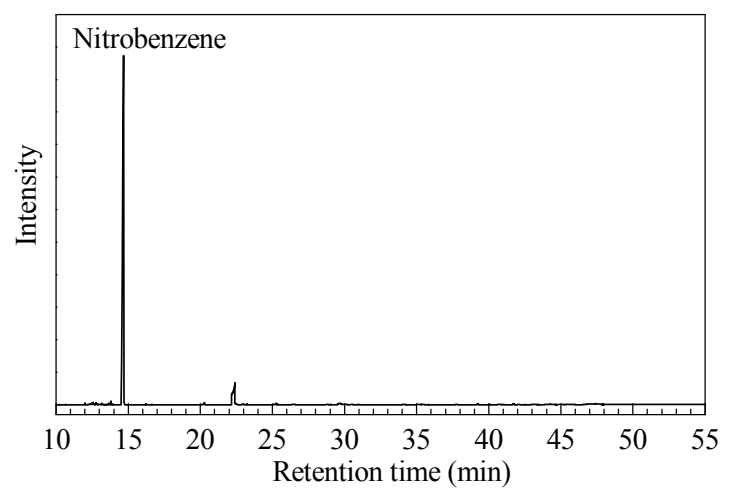

Fig. 4. Gas chromatography-mass spectrum of the reaction of 4-iodoanisole with hydroxybenzotriazole.

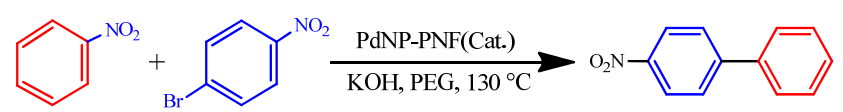

Scheme 3. Investigation of biaryl synthesis promoted by the nanofiber-based catalyst under the optimized reaction conditions.

\section{Table 3}

Reusability of the nanofiber catalyst in the cross coupling of 4-iodoanisole with hydroxybenzotriazole.

\begin{tabular}{lcccc}
\hline Run & 1 & 2 & 3 & 4 \\
\hline Yield (\%) & 90 & 88 & 86 & 82 \\
\hline
\end{tabular}

\section{Conclusions}

Hydroxybenzotriazole was used a phenylating agent for the first time in an approach using PdNP-PNF as a new and efficient catalyst for phenylating aryl halides. The important features of this procedure are use of PNFs as an organic and environmentally friendly support, and C-C bond formation using a phosphine-free system. We believe that the present protocol is an interesting addition to existing methodologies.

\section{Acknowledgments}

The authors thank the Research Facility of Ilam University, Ilam, Iran, for financial support of this research project.

\section{References}

[1] B. B. Lakshmi, P. K. Dorhout, C. R. Martin, Chem. Mater., 1997, 9, 857-862.

[2] A. Ghorbani-Choghamarani, B. Tahmasbi, New. J. Chem., 2016, 40, 1205-1212.

[3] M. Zaarour, M. El-Roz, B. Dong, R. Retoux, R. Aad, J. Cardin, C. Dufour, F. Gourbilleau, J. P. Gilson, S. Mintova, Langmuir, 2014, 30, 6250-6256.

[4] D. Astruc, Tetrahedron: Asymmetry, 2010, 21, 1041-1054.

[5] M. Nikoorazm, A. Ghorbani-Choghamarani, M. Khanmoradi, RSC Adv., 2016, 6, 56549-56561.

[6] M. Egashira, H. Takatsuji, S. Okada, J. I. Yamaki, J. Power Sources, 2002, 107, 56-60.

[7] B. Xue, P. Chen, Q. Hong, J. Y. Lin, K. L. Tan, J. Mater. Chem., 2001, $11,2378-2381$.

[8] A. Ghorbani-Choghamarani, Z. Taherinia, RSC. Adv., 2016, 6, 59410-59421.

[9] A. S. Nain, J. C. Wong, C. Amon, M. Sitti, Appl. Phys. Lett., 2006, 89, 183105/1-183105/3. 


\title{
Graphical Abstract
}

Chin. J. Catal., 2017, 38: 469-474 doi: 10.1016/S1872-2067(17)62586-X

Synthesis of biaryls using palladium nanoparticles immobilized on peptide nanofibers as catalyst and hydroxybenzotriazole as novel phenylating reagent

Arash Ghorbani-Choghamarani* ,Zahra Taherinia

Ilam University, Iran

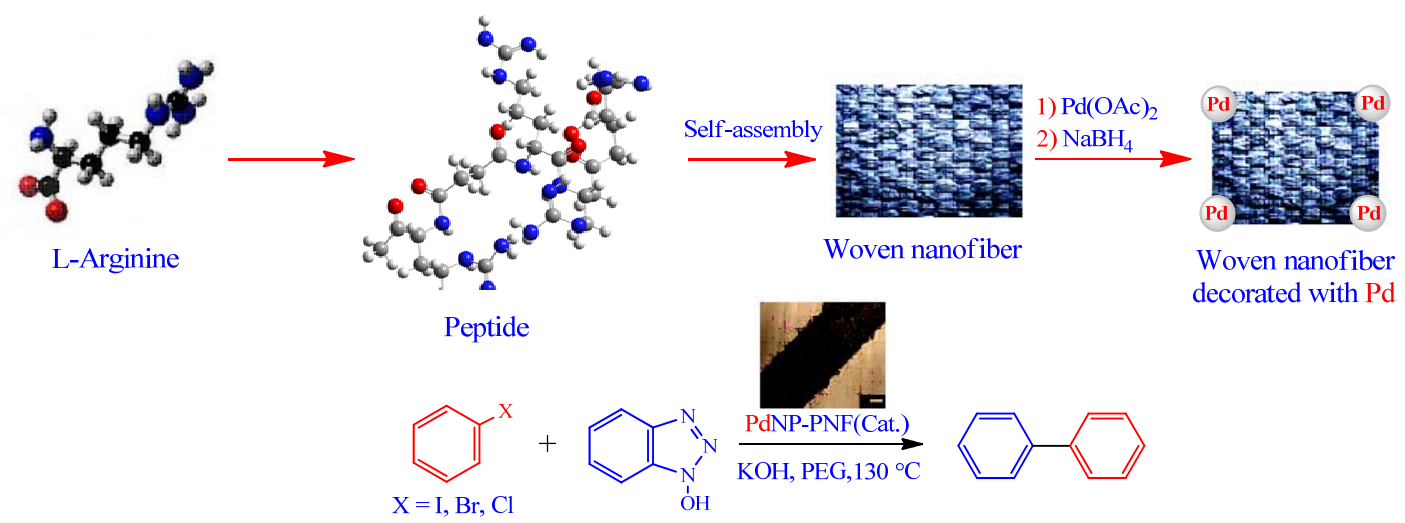

Pd nanoparticles supported on peptide nanofibers (PdNP-PNF) represent unique catalytic activity for the phenylation of aryl halides by hydroxybenzotriazole as new phenylating agent under green reaction conditions.

[10] L. Feng, S. H. Li, H. J. Li, J. Zhai, Y. L. Song, L. Jiang, D. B. Zhu, Angew. Chem. Int. Ed., 2002, 114, 1269-1271.

[11] G. J. Liu, J. F. Ding, L. J. Qiao, A. Guo, B. P. Dymov, J. T. Gleeson, T. Hashimoto, K. Saijo, Chem. Eur. J., 1999, 5, 2740-2749.

[12] J. M. Deitzel, J. Kleinmeyer, D. Harris, N. C. Beck Tan, Polymer, 2001, 42, 261-272.

[13] M. Mondal, S. K. Bharadwaj, U. Bora, New J. Chem., 2015, 39, 31-37.

[14] D. G. Hall, Boronic Acids: Preparation and Applications in Organic
Synthesis and Medicine, Wiley-VCH Verlag GmbH \& Co. KGaA, Weinheim, 2005.

[15] E. Valeur, M. Bradley, Chem. Soc. Rev., 2009, 38, 606-631.

[16] N. B. Colthup, L. H. Daly, S. E. Wiberley, New York, 1975. Kemp, A. J. Text. I., 1958, 49, T44.

[17] G. Odegard, K. Searles, M. Kumosa, Compos. Sci. Technol., 2001, 61, 2501-2510.

[18] A. Rostami, A. Rostami, A. Ghaderi, J. Org. Chem., 2015, 80, 8694-8704.

\section{肽纳米纤维固载Pd纳米颗粒为催化剂、羟基苯并三唑为新型苯基化试剂合成联芳}

\author{
Arash Ghorbani-Choghamarani *, Zahra Taherinia \\ 伊拉姆大学理学院化学系, 伊拉姆69315516, 伊朗
}

摘要: 研究了肽纳米纤维负载的Pd纳米颗粒催化卤代芳烃与羟基苯并三坐的直接偶合反应. 结果表明, 该偶合反应可在简 单、绿色及温和的条件下进行, 并可以较高产率生成相应的联芳. 本文首次采用羟基苯并三唑作为苯基化试剂, 且将肽纳 米纤维作为一种新型可循环使用的载体, 因而对现有合成方法是一个有益补充.

关键词: 缩氨酸纳米纤维; 羊基苯并三唑; 联芳; 聚乙二醇; 钯

收稿日期: 2016-08-28. 接受日期: 2016-10-10. 出版日期: 2017-03-05.

*通讯联系人. 电话/传真: +98-841-2227022; 电子信箱: a.ghorbani@mail.ilam.ac.ir, arashghch58@yahoo.com

本文的英文电子版由Elsevier出版社在ScienceDirect上出版(http://www.sciencedirect.com/science/journal/18722067). 